DOI:10.17951/h.2020.54.3.101-116

\begin{tabular}{lcc}
\hline & A N N A L E S \\
UNIVERSITATIS MARIAE CURIE-SKŁODOWSKA & LUBLIN - POLONIA \\
VOL. LIV, 3 & SECTIO H \\
\hline
\end{tabular}

\title{
ROBERT ZAJKOWSKI
}

robert.zajkowski@umcs.lublin.pl

Maria Curie-Skłodowska University. Faculty of Economics

5 Marii Curie-Skłodowskiej Sq., 20-400 Lublin, Poland

ORCID ID: https://orcid.org/0000-0002-0021-7977

\section{BEATA ŻUKOWSKA}

beata.zukowska@poczta.umcs.lublin.pl

Maria Curie-Skłodowska University. Faculty of Economics

5 Marii Curie-Skłodowskiej Sq., 20-400 Lublin, Poland

ORCID ID: https://orcid.org/0000-0002-5644-6963

\section{Family Businesses during the COVID-19 Crisis - Evidence from Poland}

Keywords: family businesses; COVID-19 crisis; ad hoc solutions; crisis management; Anti-Crisis Shield JEL: G28; G32; H12; L20

How to quote this paper: Zajkowski, R. \& Żukowska, B. (2020). Family Businesses during COVID-19 Crisis - Evidence from Poland. Annales Universitatis Mariae Curie-Skłodowska, sectio H-Oeconomia, Vol. 54, No. 3.

\footnotetext{
Abstract

Theoretical background: Family businesses are a specific group of enterprises in which family bonds play a vital role in determining the economic and noneconomic goals of the business. The subject literature emphasises the long-term focus of family businesses which is on continuity, futurity and perseverance. During the COVID-19 crisis, unique family business traits can allow these entities to access useful resources and take positive actions such as forging strong networking relationships, tapping into local idiosyncratic knowledge, exercising rapid response, having flexibility and exercising trust with caution. This suggests that family businesses might also react to the COVID-19 crisis in their own distinctive ways using their unique attributes.
} 
Purpose of the article: In this paper we will show how family businesses deal with coronavirus restrictions and what measures they undertook during this challenging period. The paper is organised around four research questions.

Research methods: This research was conducted using a sample of 167 family businesses. Primary data related to reactions of family businesses facing the COVID-19 crisis were collected in April and at the beginning of May 2020. To achieve the goals of this study, we carried out such research methods and procedures as fractal analyses, descriptive statistics, statistical comparison of means and subjective classification of the factors.

Main findings: For family businesses, a sudden fall in revenue was a common result of COVID-19 restrictions in the Polish economy. In the case of the majority of surveyed family firms, revenues fell by $44 \%$, and in the next 2 to 3 months businesses expected additional decreases of $39.8 \%$. More than $65 \%$ declared a stable level of employment, but more than a quarter of surveyed family firms showed an average dip in firm employment of $15.7 \%$ and expected further job losses at around $13.1 \%$. To protect businesses against the negative effects of the pandemic, surveyed family firms undertook several $a d$ hoc measures. We divided the analysed reactions to COVID into three groups: proactive, neutral and progressive. We noticed that the most common measures were those marked as "neutral", or those which neither expanded nor retrenched the business in the short term. This observation suggests that family businesses might choose "persevering" as their first strategic response to the sudden crisis. We also found that "proactive" measures were undertaken in family businesses which evaluated their probability of survival as higher than businesses that indicated "neutral" or "defensive" reactions. In addition, we isolated statistically significant differences in family firms' average probability of survival among the firms which introduced particular neutral and defensive measures and those which did not. On this basis we can conclude that the lower the perceived probability of survival is, the more retrenchment-oriented types of measures begin to be taken. Additionally, it should be mentioned that so-called anti-crisis shields implemented by the Polish government were assessed as inadequately supportive of business entities' survival.

\section{Introduction}

Family firms are perceived as a unique group of enterprises in which family bonds play a crucial role in determining its economic and noneconomic goals (Basco, 2017; Węcławski \& Żukowska, 2019). In the subject literature its long-term orientation is one of the fundamental characteristics mentioned (Cater \& Justis, 2009; Chrisman, Chua, Pearson, \& Barnett, 2012) which is reflected by continuity, future orientation and perseverance (Brigham, Lumpkin, Payne, \& Zachary, 2014). It could be assumed that these values might help a business survive the crisis period and alleviate potential adverse consequences. Some works in the extant literature describe how family businesses operate during different kinds of economic shocks (Bauweraerts, 2013; Cater \& Beal, 2014; Lins, Volpin, \& Wagner, 2013; Minichilli, Brogi, \& Calabrò, 2015). The accumulated knowledge in this subject could be useful in analyses of family businesses' reactions to the current COVID- $19^{1}$ pandemic.

In this case, sudden COVID-19 restrictions were another challenge that family businesses had to face. We examined Polish family businesses to find out how they deal with these challenges and what their ad hoc reactions to the pandemic were. We assumed the measures they undertook would suggest which strategic response

1 COVID-19 is described by media, practitioners and scientists as "SARS-CoV-2" or "coronavirus". 
they decided to follow. According to Wenzel, Stanske and Lieberman (2020), during the coronavirus crisis four types of strategic business responses can be indicated: retrenchment, persevering, innovating and exit.

The aim of this paper is to delineate how these entities deal with sudden coronavirus restrictions and what measures they undertook during this challenging period. The paper is organised as follows. Firstly, building on previous works in the literature on family businesses by focusing on particular traits like long-term orientation, continuity, futurity and perseverance, we introduced the theoretical background on how family businesses operate during different kinds of economic crises. Subsequently, we presented an overview related to the COVID-19 crisis in Poland, stages of crisis development and restrictions that were implemented by the Polish government due to the pandemic situation. On the basis of theoretical considerations and situation overview, we formulated the thesis of this paper and research questions. As the next step, we presented the methodology, sample description and general results achieved. Finally, we drew conclusions and formulated generalisations.

\section{Literature review}

\section{Family businesses during the crisis}

Family businesses are a specific group of enterprises in which family bonds play a vital role in determining economic and noneconomic goals (Basco, 2017; Węcławski \& Żukowska, 2019). The subject literature emphasises its long-term orientation (Cater \& Justis, 2009; Chrisman et al., 2012) which demonstrates continuity, futurity and perseverance (Brigham et al., 2014). Nurturing these values might help businesses to survive the crisis and alleviate potential adverse consequences. Family involved in these shared businesses not only care about the future of the enterprise but also about the family's ongoing reputation. This might affect its potential decisions connected with the solutions and tools which are used during trying economic times.

The extant subject literature describes how family businesses operate and perform during different kinds of economic shocks. The most convincing evidence is from the 2008-2009 financial crisis. Lins et al. (2013) revealed that during that time publicly listed family businesses underperform nonfamily businesses. This situation is caused by underinvestment, which is an effect of the survival-oriented business strategy. Investments during the crisis are more reduced in family businesses in comparison to their non-family counterparts. As a result, they suffer more than other businesses during stock market downturns (Lins et al., 2013). The authors also noticed that investments are curtailed in family-controlled companies that were in relatively good financial condition prior to the pandemic. This phenomenon occurred when such a company is a part of a family business group, and the crisis hits any other company in a "holding". 
Different results were obtained by Bauweraerts (2013) who showed that family businesses outperform their nonfamily counterparts during the crisis. This is a result of their greater resilience through family involvement. The resilience itself can be explained by the "competitive advantage" hypothesis that was rooted in the resource-based view of the firm and stewardship theory (Minichilli et al., 2015). This approach suggests that specific family commitment to family firms can create and develop specific, unique resources which are unobtainable for nonfamily businesses (Habbershon \& Williams, 1999; Sirmon \& Hitt, 2003). Family firms additionally benefit from unique motivation and support from family members. This support can take the form of free or loaned labour, low interest loans or additional capital investments (Siakas, Naaranoja, Vlachakis, \& Siakas, 2014; Sirmon \& Hitt, 2003). In addition, family involvement in a business promotes flexibility which is an extremely important attribute during the COVID crisis (Bauweraerts, 2013). Thanks to less formalised structures (Songini, 2006) and greater solidarity with stakeholders (Berrone, Cruz, \& Gomez-Mejia, 2012; Miller \& Le Breton-Miller, 2006) family businesses might seek more proactive and innovative ways to alleviate the consequences of sudden market and social shocks. The uniqueness of a family business in dealing with the critical circumstances was also well illustrated by Cater and Beal (2014), who studied their reactions to externally induced crises (the BP oil spill in 2010, for example). The authors examined family businesses in coastal parishes of Louisiana (USA) who were affected by the pollution resulting from the BP oil spill. They revealed that the unique traits of a family business become especially evident during a crisis: for example, strong networking relationships, local idiosyncratic knowledge, rapid response, flexibility and exercising trust with caution (Cater \& Beal, 2014). This suggests that family businesses might also react to the COVID-19 crisis in their own distinctive ways, using their unique skills and abilities.

Initial studies related to family business in the COVID-19 crisis seem to confirm the findings in question. Quality research conducted in five European countries revealed extraordinary solidarity with employees and external stakeholders, which are powerful tools that ensure mutual support and create a sense of solidarity while facing the crisis together (Kraus, Clauss, Breier, Gast, Zardini, \& Tiberius, 2020). Exceptional treatment of employees during the crisis period was also confirmed in the study conducted by Floren, Berent-Braun and Bles-Temme (2020) among Dutch family firms. They showed that retaining employees is much more important than, for example, attaining a dividend payout.

Different measures taken by family firms represent different strategic responses to COVID-19 crisis. According to Wenzel, Stanske and Lieberman (2020) four types of responses can be specified: retrenchment, persevering, innovating and exit. "Retrenchment" refers to reductions in costs, assets, products, product lines and overheads. "Persevering" means retaining the status quo and aiming to sustain the firm's business activities. "Innovating" is connected with actions directed at seizing 
opportunities and adapting business activities to a changing environment. "Exit" means the discontinuation of the business (Wenzel et al., 2020).

Kraus et al. (2020) discovered that family businesses' strategic responses are mainly pure perseverance or a combination of perseverance, innovation and retrenchment. These results suggest that the long-term orientation characteristic of family firms might naturally direct them to take the most moderate steps. However, implementing such steps requires having sufficient liquidity before the crisis and hoping this will be sufficient in the long term.

\section{Situation overview: The COVID-19 crisis in Poland}

The first COVID-19 confirmed infection in Poland was reported on 4 March 2020. On 10 March, the first restrictions were introduced (e.g., cancelling mass events). The next day, classes in kindergartens, schools and universities were suspended. On 13 March, came the decision about closing restaurants and places where people gather in mass groups. Further restrictions, announced on 24 March and 31 March, were the most severe for the Polish economy, as nonessential travel was prohibited and hotels, rehabilitation salons, hairdressers and other beauty industry businesses were closed. In addition, employers were forced to ensure safe work conditions for their employees, including access to disinfectant liquids and social distancing between work stations (www.gov.pl; www.300gospodarka.pl/live/koronawirus-nowe-ograniczenia-w-polsce). From this point, Polish businesses started to feel the effects of the so-called Great Lockdown.

In order to alleviate the adverse effects of the lockdown, the Polish government implemented its economy support programme as one of the pillars of the Anti-Crisis Shield. The first version of the Anti-Crisis Shield (Anti-Crisis Shield 1.0) in the form of a special legal act was published on 31 March. However, as the epidemic was worsening, additional solutions were required. Hence, there were subsequent legal acts implemented, dubbed Anti-Crisis Shield 2.0, 3.0 and so on. The summary of the most important solutions dedicated to the support of enterprises in each version of the shield is presented in Table 1 .

Table 1. Anti-Crisis Shield in Poland

\begin{tabular}{|c|c|c|}
\hline $\begin{array}{c}\text { Anti-Crisis } \\
\text { Shield stages }\end{array}$ & $\begin{array}{c}\text { Announcement } \\
\text { date }\end{array}$ & Chosen supporting tools for enterprises (exclusively) \\
\hline Shield 1.0 & 31 March 2020 & $\begin{array}{l}\text { - co-financing of employees' salaries subject to lockdown } \\
\text { - co-financing of the salaries of employees subject to reduced working hours } \\
\text { - flexible working hours } \\
\text { - standstill benefit } \\
\text { - microloans up to PLN 5,000 (circa EUR 1,200) } \\
\text { - exemption from social insurance contributions (only for businesses which } \\
\text { employ less than } 10 \text { people) } \\
\text { - tax solutions: suspension of collection of the extension fee, extension of the } \\
\text { deadline for advance payments for payroll tax }\end{array}$ \\
\hline
\end{tabular}


Pobrane z czasopisma Annales H - Oeconomia http://oeconomia.annales.umcs.pl Data: 26/04/2023 16:20:46

\begin{tabular}{|l|l|l|}
\hline $\begin{array}{c}\text { Anti-Crisis } \\
\text { Shield stages }\end{array}$ & $\begin{array}{c}\text { Announcement } \\
\text { date }\end{array}$ & \multicolumn{1}{c|}{ Chosen supporting tools for enterprises (exclusively) } \\
\hline Shield 2.0 & 16 April 2020 & $\begin{array}{l}\text { - exemption from social insurance contributions was extended for businesses } \\
\text { which employ 10-49 people } \\
\text { - microloans up to PLN 5,000 (circa EUR 1,200) are dedicated also to busi- } \\
\text { nesses with no employees (sole traders) } \\
\text { - standstill benefit can be paid more than once (three times) }\end{array}$ \\
\hline Shield 3.0 & 14 May 2020 & $\begin{array}{l}\text { - no need to obtain a new permit or declaration in the event of a change in } \\
\text { the foreigner's working conditions }\end{array}$ \\
\hline Shield 4.0 & 19 June 2020 & $\begin{array}{l}\text { - obligation to take the overdue leave } \\
\text { - limitation of the amount of severance pay } \\
\text { - co-financing for the remuneration of employees who have not been subject } \\
\text { to downtime, economic downtime or reduced working time } \\
\text { - simplified restructuring procedure } \\
\text { - protection of enterprises against takeovers by foreign entities } \\
\text { - possibility of including contractual penalties in costs }\end{array}$ \\
\hline
\end{tabular}

Source: Authors' own study based on (www.dziennikustaw.gov.pl/; www.pracodawcyrp.pl/tarcza-antykryzysowa)

Apart from presented solutions, on 29 April 2020, Polish Development Fund Group started Financial Shield for Enterprises Programme. The goal of this project was to support small, medium and large businesses financially through subventions, loans and capitalisations (www.pfr.pl/tarcza.html). At the end of July 2020, about PLN 60 billion was redistributed through the banks to companies that fulfil requirements for this support.

On 16 April, the initial plan for a "defrosting the economy" was presented. It was divided into four stages; however, the date (20 April) was given only for the first stage of defrosting. The first "loosing" action was to increase the maximum number of clients in shops. On 4 May, hotels and shopping centres were open again (the second stage of defrosting). From 18 May, beauticians, hairdressers and restaurants were open for business again albeit with special strict sanitary requirements. From 6 June, fitness clubs, swimming pools, cinemas, theatres, amusement parks and massage salons were opened again.

The described circumstances may serve as a "laboratory" for observations of specific family business behaviours during an unexpected crisis. The goal of this paper is to show how these entities deal with sudden restrictions and what measures they undertake during this challenging period. The study is guided by the following research questions:

1) How were family businesses affected by the lockdown restrictions?

2) What measures did family businesses undertake to combat the sudden crisis?

3) How does the perception of the family business' future correspond with the undertaken measures?

4) How was the Anti-Crisis Shield evaluated by family businesses?

The rest of our paper was devoted to collecting answers to these research questions. 


\section{Research methods}

The primary data were collected from 14 April 2020 to 6 May 2020 via mail survey. According to the presented situation overview, this was the peak period of lockdown restrictions (so-called Great Lockdown). The first announcements about "defrosting" (gradual easing of economic and social restrictions) plans were made, and the Anti-Crisis Shield, in its first and second versions, was implemented (see Figure 1).

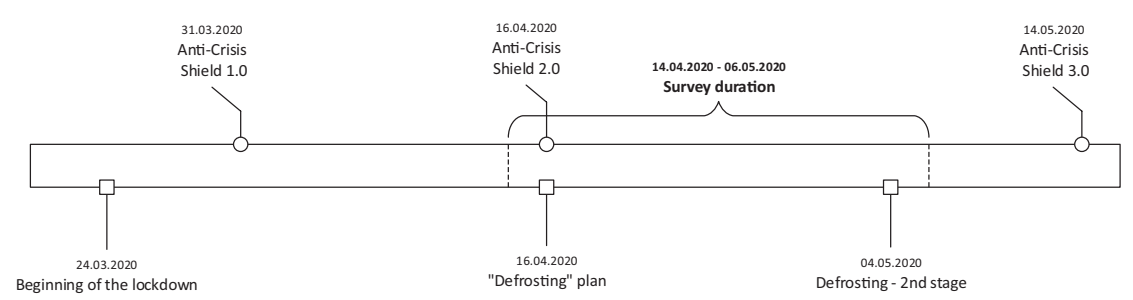

Figure 1. COVID-19 in Poland - timeline

Source: Authors' own study.

The list of family businesses was created by searching different media, national registers and by checking the family business forums, foundations, websites and so on. In total, there were 8,428 questionnaires sent to potential representatives of family businesses. A total of 272 (3.2\%) business entities answered. From this group we isolated 202 (2.4\%) family firms. As a method of narrowing down the family firms, we used a self-classification approach to the businesses in this group (Frishkoff, 1995; Zajkowski \& Życzyński, 2014). This means that representatives of these businesses declared whether their business was a family firm or not. After the rejection of incompletely filled questionnaires, the final sample totalled 167 (2\%) family firms. It should be mentioned that business entities in the sample did not answer all questions, or in some cases they answered "not applicable".

Descriptive analysis of the tested sample allows us to identify the following characteristics. The oldest declared family firm had been in business for 92 years, the youngest firm was 2 years old. Average age of the firms was 23.6 years. Most enterprises took the form of an LLC company $(50.8 \%)$, or sometimes they operated as general partnerships $(16.9 \%)$ or sole traders $(16.1 \%)$. Limited partnerships $(8.1 \%)$, joint-stock companies $(3.2 \%)$ or other forms were sporadic. The enterprises came from various industries. The majority represented were from the services sector $(39.5 \%)$, the next largest group was from the industrial sector $(25.8 \%)$, while the same percentage declared multisector engagement. There were $8.9 \%$ of businesses representing the trade sector.

The majority of the surveyed enterprises (40.3\%) employed from 10 to 49 employees and $38.7 \%$ employed up to 9 people. The rest (21.0\%) had over 49 employees. The average number employed was 49.4. Average revenue of surveyed businesses 
equalled PLN 37,831.19. Based on the classification adopted by the European Union (European Commission, 2009), medium-sized enterprises were dominant in terms of employment, but the majority were small-scale operations in terms of revenues.

\section{Results}

Taking into consideration this paper's initial research questions, we extracted four areas of COVID-19 crisis impact on family businesses. Firstly, we asked representatives of business entities how the crisis had affected them and how they would be affected in the proceeding 2 to 3 months in terms of employee and revenue stability. The figures revealed two tendencies. In the area of employment, the majority of businesses (73\%) tried to sustain their current levels of employment, and $67.3 \%$ would not lay off any staff in the months to come. Slightly more than $22.1 \%$ reduced their employee numbers, and around $30 \%$ were planning to cut staff within a few months (see Table 2). Less than 5\% of businesses (13 in total) declared that numbers of employed workers at their firms had risen or would increase in the near future.

Table 2. Family businesses that declared changes in the area of employment and revenues

\begin{tabular}{|l|c|c|c|c|c|c|}
\hline \multicolumn{1}{|c|}{ Performance } & $\begin{array}{c}\text { Decreased } \\
(\mathrm{N})\end{array}$ & $\begin{array}{c}\text { Without } \\
\text { changes } \\
(\mathrm{N})\end{array}$ & $\begin{array}{c}\text { Increased } \\
(\mathrm{N})\end{array}$ & $\begin{array}{c}\text { Decreased } \\
(\%)\end{array}$ & $\begin{array}{c}\text { Without } \\
\text { changes } \\
(\%)\end{array}$ & $\begin{array}{c}\text { Increased } \\
(\%)\end{array}$ \\
\hline $\begin{array}{l}\text { Changes in employee numbers } \\
\text { (persons) }\end{array}$ & 37 & 122 & 8 & 22.1 & 73.0 & 4.8 \\
\hline $\begin{array}{l}\text { Predicted changes in employee } \\
\text { numbers in 2-3 months (persons) }\end{array}$ & 49 & 111 & 5 & 29.7 & 67.3 & 3.0 \\
\hline Changes in revenues (percentage) & 109 & 44 & 13 & 65.7 & 26.5 & 7.8 \\
\hline $\begin{array}{l}\text { Predicted changes in revenues in } \\
\text { 2-3 months (percentage) }\end{array}$ & 107 & 47 & 12 & 64.5 & 28.3 & 7.2 \\
\hline
\end{tabular}

Source: Authors' own study.

The majority of family businesses (65.7\%) reported a decrease in revenue, and a similar percentage $(64.5 \%)$ were expecting revenue to go down in two to three months. More than a quarter (26.5\%) declared no changes in revenue, and $28.3 \% \mathrm{did}$ not anticipate a fall in revenue anytime soon. Only $7.8 \%$ of surveyed family businesses noticed a positive change in revenue, and $7.2 \%$ predicted an increase in revenue.

On average, decreases in employment accounted for 7.8 persons, and it was expected that in the next few months, reductions in staff would account for 5.5 additional persons (see Table 3). In the group of family businesses that declared increases in employment, the relevant figure showed an average of 8.6 new hires, and these businesses were expecting further growth of 3.2 persons on average.

An average fall in revenue was $44 \%$, and the prediction for the next few months was a further reduction of $39.8 \%$. These family businesses that declared increases 
in revenue achieved a $46.8 \%$ growth rate and expected their income would increase by $27.7 \%$ in two to three months.

Table 3. Average changes in employment and revenue

\begin{tabular}{|l|c|c|}
\hline \multicolumn{1}{|c|}{ Performance } & Average decrease & Average increase \\
\hline Changes in employee numbers & 7.8 persons & 8.6 persons \\
\hline Predicted changes in employee numbers & 5.5 persons & 3.2 persons \\
\hline Changes in revenue & $44.0 \%$ & $46.8 \%$ \\
\hline Predicted changes in revenue & $39.8 \%$ & $27.7 \%$ \\
\hline
\end{tabular}

Source: Authors' own study.

The next phase of the research was devoted to identifying which measures (reactions) were undertaken by family businesses as a response to COVID-19 crisis restrictions. We referred to them as ad hoc short-term reactions. We classified these measures (reactions) into three groups: proactive, neutral and defensive. Proactive responses are focused on boosting family business operational processes during the COVID-19 crisis. Neutral responses do not require significant reorganisation of business operational processes, or changes can be implemented gradually according to accessible formal and legal requirements. Defensive reactions refer to active reductions to the current financial and economic burden of the business. This division was illustrated in Figure 2.

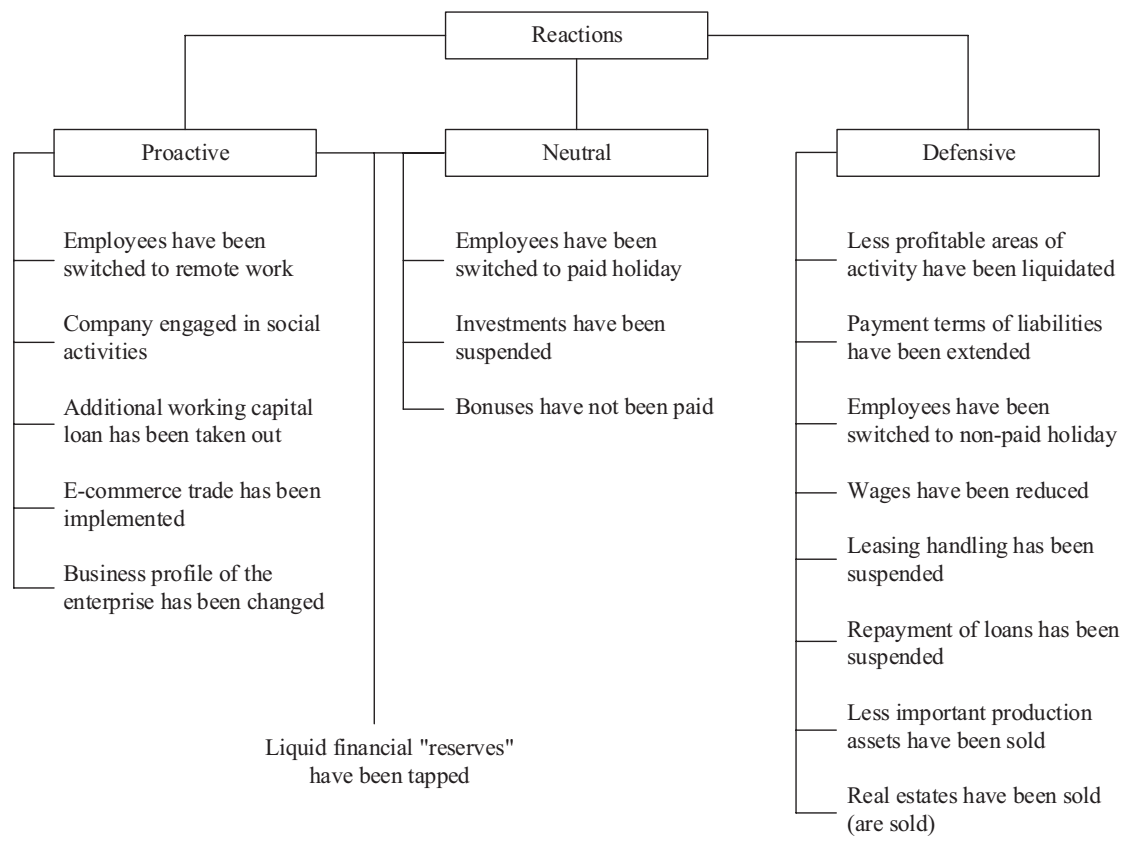

Figure 2. Division of businesses' ad hoc reaction to the COVID-19 crisis 
An analysis of response structures revealed which percentage of family businesses implemented particular measures. Overall, 70\% of business entities suspended investments, $53.3 \%$ switched employees to remote work and 52.4\% were forced to access liquid financial "reserves" (see Table 4).

Table 4. Ad hoc reactions of family businesses facing the COVID-19 crisis

\begin{tabular}{|l|c|c|c|c|l|}
\hline \multicolumn{1}{|c|}{ Reactions/actions/solutions } & No (N) & No (\%) & Yes (N) & Yes (\%) & Kind of activity \\
\hline Investments have been suspended & 42 & 30.00 & 98 & 70.0 & Neutral \\
\hline Employees have been switched to remote work & 56 & 46.67 & 64 & 53.3 & Proactive \\
\hline Liquid financial "reserves" have been tapped & 60 & 47.62 & 66 & 52.4 & Proactive/Neutral \\
\hline Employees have been switched to paid holiday & 72 & 50.35 & 71 & 49.7 & Neutral \\
\hline Bonuses have not been paid & 70 & 57.85 & 51 & 42.1 & Neutral \\
\hline Payment terms of liabilities have been extended & 82 & 58.99 & 57 & 41.0 & Defensive \\
\hline E-commerce trade has been implemented & 69 & 61.06 & 44 & 38.9 & Proactive \\
\hline Company engaged in social activities & 93 & 67.39 & 45 & 32.6 & Proactive \\
\hline Less profitable areas of activity have been liquidated & 80 & 69.57 & 35 & 30.4 & Defensive \\
\hline Wages have been reduced & 99 & 69.72 & 43 & 30.3 & Defensive \\
\hline Repayment of loans has been suspended & 95 & 76.61 & 29 & 23.4 & Defensive \\
\hline Leasing handling has been suspended & 105 & 83.33 & 21 & 16.7 & Defensive \\
\hline Employees have been switched to non-paid holidays & 118 & 85.51 & 20 & 14.5 & Defensive \\
\hline Less important production assets have been sold & 109 & 89.34 & 13 & 10.7 & Defensive \\
\hline Additional working capital loan has been taken out & 124 & 90.51 & 13 & 9.5 & Proactive \\
\hline Business profile of the enterprise has been changed & 128 & 92.75 & 10 & 7.2 & Proactive \\
\hline Real estate has been sold (are sold) & 114 & 98.28 & 2 & 1.7 & Defensive \\
\hline
\end{tabular}

Source: Authors' own study.

A significant percentage of businesses switched employees to paid holidays (49.7\%), stopped paying bonuses (42.1\%) and extended payment terms of liabilities (41\%). Between $20 \%$ to $30 \%$ of surveyed businesses implemented e-commerce, engaged in social activities connected with prevention of COVID-19, liquidated less profitable areas and reduced wages. Less than $20 \%$ of family business suspended repayment of loans or/and leasing, switched employees to non-paid holidays, sold part of their production assets (less significant) or/and real estate, took out working capital loans and changed their business profile (see Table 4).

In the subsequent stage of analyses we calculated the probability of family business survival during the COVID-19 pandemic. Respondents were asked to assess the likelihood of survival on a Likert scale $(1$ - it is certain that the business will collapse, 10 - it is certain that the business will survive). Next, this scale was recalculated to intervals of 0 to $100 \%$ through implementation of the zero unitarisation method (Kukuła, 1999). Figures showed that the average likelihood of survival for surveyed business entities was 74.4\% (SD 23.1\%). Divergences in the probability of survival were not confirmed statistically if legal forms and sectors were taken into consideration, according to the Kruskal-Wallis test $p=0.701$ and $p=0.562$, respectively. Similarly, U Mann-Whitney tests did not confirm differences between 
family businesses that were managed ( $p=0.054)$ and owned $(p=0.95)$ only by first generation (generation of founders) and future generations of the family.

Subsequently, we conducted a more profound study that was focused on answering research question 3 . With more profound analyses we isolated the probability of survival if a particular solution was implemented or not. We analysed separately the likelihood of the family business surviving for each kind of measure (reaction) that was or was not implemented. The differences between these were tested by using the U Mann-Whitney test. Detailed results were presented in Table 5. Additionally, we marked measures (reactions) in accordance with the divisions presented in Figure 2. Generally, with the exception of switching employees to remote work, in all other cases the likelihood of survival was perceived lower by family businesses that undertook particular activities. Additionally, in 11 out of 17 analyses the differences were statistically significant.

In the case of such activities as switching employees to remote work, engaging in social activities, taking out additional working capital loans, switching employees to paid holidays and implementation of e-commerce trade undertaken by the family firm, the probability of survival on average was around $70 \%$. Additionally, four out of five measures were classified as "proactive" (one was neutral).

For the next group of activities implemented by family businesses, the probability of survival was in the range of $60 \%$ to $70 \%$ (tapping liquid financial "reserves", suspending investments, stopping bonus payments, liquidating less profitable areas of business interest, extending payment terms of liabilities, switching employees to nonpaid holidays, changing the business profile and reducing wages). This group encompasses all kinds of reactions: proactive (1) proactive/neutral (2), neutral (3) and defensive (4) (see Table 5).

The last group of reactions encompasses those family firms for whom probability of survival was below $60 \%$ (suspending leasing payments, suspending loan repayments, selling nonessential production assets and real estate). All of these were deemed to be defensive. More profound analyses devoted to these ad hoc reactions were presented in the section "Discussions and conclusions".

It should also be noted that the Polish government introduced on 31 March the Anti-Crisis Shield 1.0 and a few weeks later the Anti-Crisis Shield 2.0 with the assumption that this action would mitigate the negative consequences of the crisis. The most important aspects of these shields have been discussed previously in this paper. In accordance with our findings, $58.6 \%$ of family businesses intended to use or did use proposed solutions, $23 \%$ were considering whether to use them and $24.4 \%$ were not interested in applying these or were "outsiders" (meaning that they did not fulfil the formal requirements for accessing these instruments). Additionally, we asked to what extent the shield will mitigate the negative effects of the crisis. For $69.8 \%$ of surveyed family businesses the positive impact of the shield will be fairly low. Almost a quarter (23.5\%) assessed it as having no influence, and only $6.7 \%$ of businesses ranked the shield as significant or very significant. 


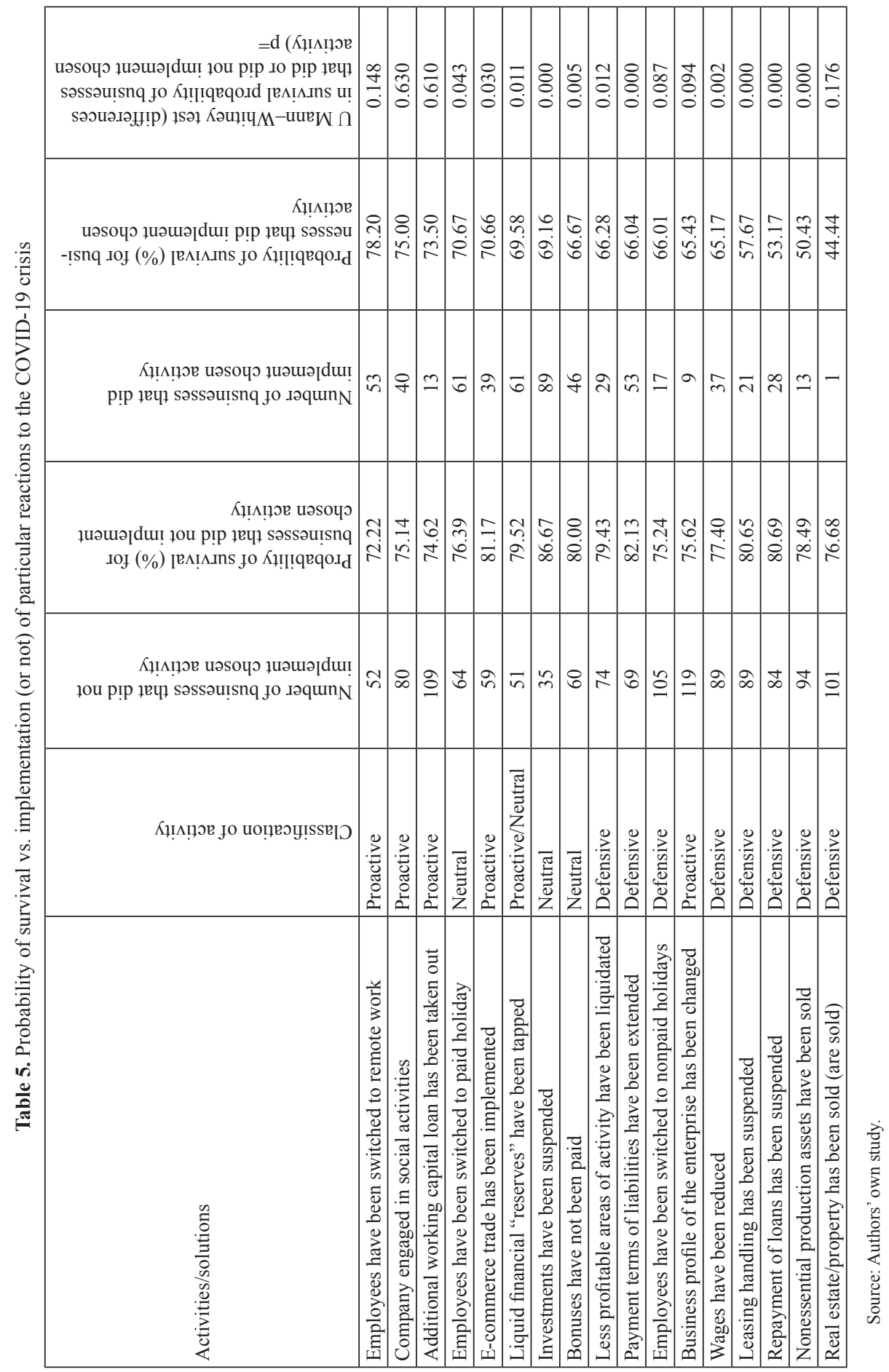




\section{Discussions and conclusions}

A sudden drop in revenue was a common consequence of COVID-19 restrictions in the Polish economy. All accessible reports on the financial health of business entities presented consistent figures. In a survey conducted in April 2020, almost 94\% of businesses were expecting decreases in revenue, and the drop would be nearly $50 \%$. Similar figures were presented by PWC (Forbes, 2020; PWC, 2020). The same negative effects were observed in employment. Reduction was predicted to reach $15.5 \%$ in the first phase of the crisis (Forbes, 2020), with the steepest drop being in a group of microbusinesses (16.6\%). In this context, our findings are in line with the figures in question (see Table 2). More importantly, the majority of surveyed family businesses first declared that they have avoided and would continue to avoid laying off employees ( $73 \%$ and $67 \%$, respectively). This observation confirms previous findings that family businesses try to be "good employers", and to some extent do care about their staff (Arregle, Hitt, Sirmon, \& Very, 2007; Neckebrouck, Schulze, \& Zellweger, 2018) even when facing temporary market downturns (Lee, 2006). If the family firm declared a reduction in employment (more than $27 \%$ of businesses), the average was $15.7 \%$, and surveyed businesses that were expecting a further drop in employment were at $13.1 \%$. Considering these figures, it can be said that the lockdown due to the COVID-19 pandemic adversely affected the economic well-being of family firms.

To prevent the negative effects of the COVID-19 crisis, surveyed family businesses took several ad hoc measures (reactions). The frequency of the implementation of these measures is the answer to the second research question in this paper. It was found that family businesses' reactions were frequently neutral and proactive/ neutral (except in the case of liquid financial "reserves" having been tapped). Other measures that were implemented by a lower percentage of businesses did not present with any consistency.

Moreover, we found that some of these actions by family firms depended on general perceptions of their future business longevity reflected by their probability of survival during the COVID-19 crisis. These findings answered the third research question. We then divided analysed reactions into three groups (proactive, neutral and progressive - see Tables 4 and 5).

It should be noted that for "proactive" solutions, the average probability of survival declared by the family businesses was relatively higher (except in the case of changing the profile of the enterprise) compared to other actions/solutions. Moreover, differences between entities which introduced a proactive solution and those that did not, in most cases, were insignificant (except in the implementation of e-commerce trade). It may suggest that family firms' anticipation of the adverse effects of COVID-19 crisis did not influence the decision of whether or not to implement this solution.

For "neutral" reactions, the probability of survival occurred on average lower compared to "proactive" actions, and we isolated statistically significant differences 
between family firms which implemented these solutions and those that did not. This leads to the conclusion that "neutral" actions are undertaken first if the business entity is facing potential negative effects of the crisis. It should be noted that neutral solutions can be implemented in line with formal legal requirements with no severe harm to stakeholders. It means that these solutions are chosen if the company is anticipating a negative (however moderate) impact of the crisis.

Majority of "defensive" solutions differ statistically between family businesses that introduced or not them. The probability of survival for family firms that implemented these defensive solutions was noticeably lower compared to other groups of solutions (proactive and neutral). These findings can mean that family businesses which undertake these defensive actions faced the most challenges from the COVID-19 crisis and tried to maintain the business using methods that could mitigate negative effects in the short term. These actions are typically connected with reduction of financial and economic burdens of the business (e.g., suspension of payments).

Analyses of the specificity of particular reactions led us to conclude that each of these reactions can be attributed to three or four of the strategic crisis responses proposed by Wenzel et al. (2020). "Proactive" responses usually mean innovative approaches; "neutral" reactions are associated with mere perseverance and "defensive" refers to retrenchment. We cannot classify at least one of our ad hoc reactions to an exit strategic approach presented in the work in question. Similar results were presented by Kraus and co-workers who after analysing businesses entities in five European countries (Austria, Germany, Italy, Liechtenstein, Switzerland) also detected business decisions that could be construed as exit strategic approaches (Kraus et al., 2020). This may suggest that the first thought of business managers is how to survive a crisis: in other words, what measures should be implemented to alleviate the negative consequences of the crisis and how to keep the firm steadily functioning. "Exit" seems to be the ultimate strategic decision. It must be stressed that survival in this case at least partly affects long-term orientation of family businesses and their propensity for over-generational functioning. Unfortunately, in answering the fourth research question, as representatives of family businesses indicated, Anti-Crisis Shields implemented by the Polish government will be of limited use in helping business entities survive during a crisis.

\section{References}

Arregle, J.L., Hitt, M.A., Sirmon, D.G., \& Very, P. (2007). The development of organizational social capital: Attributes of family firms. Journal of Management Studies, 44(1), 73-95. doi:10.1111/j.1467-6486.2007.00665.x

Basco, R. (2017). "Where do you want to take your family firm?" A theoretical and empirical exploratory study of family business goals. Cuadernos de Economía y Dirección de La Empresa, 20(1), 28-44. doi:10.1016/j.brq.2016.07.001 
Bauweraerts, J. (2013). How do private family firms face the crisis? Empirical evidence from Belgium. International Business Research, 6(8). doi:10.5539/ibr.v6n8p91

Berrone, P., Cruz, C., \& Gomez-Mejia, L.R. (2012). Socioemotional wealth in family firms: Theoretical dimensions, assessment approaches, and agenda for future research. Family Business Review, 25(3), 258-279. doi:10.1177/0894486511435355

Brigham, K.H., Lumpkin, G.T., Payne, G.T., \& Zachary, M.A. (2014). Researching long-term orientation: A validation study and recommendations for future research. Family Business Review, 27(1), 72-88. doi: $10.1177 / 0894486513508980$

Cater, J.J., \& Justis, R.T. (2009). The development of successors from followers to leaders in small family firms: An exploratory study. Family Business Review, 22(2), 109-124. doi:10.1177/0894486508327822

Cater, J.J., \& Beal, B. (2014). Ripple effects on family firms from an externally induced crisis. Journal of Family Business Management, 4(1), 62-78. doi:10.1108/JFBM-02-2013-0006

Chrisman, J.J., Chua, J.H., Pearson, A.W., \& Barnett, T. (2012). Family involvement, family influence, and family-centered non-economic goals in small firms. Entrepreneurship: Theory and Practice, 36(2), 267-293. doi:10.1111/j.1540-6520.2010.00407.x

European Commission, (2009, November). Final report of the expert group overview of family - business - relevant issues. Challenges, 1-33.

Floren, R., Berent-Braun, M., \& Bles-Temme, L. (2020). Family businesses and the corona crisis (COV$I D-19)$. doi:10.13140/RG.2.2.24894.64324

Forbes. (2020). Koronawirus w Polsce. Jak COVID-19 uderza w firmy. Retrieved from https://www.forbes. $\mathrm{pl} /$ gospodarka/koronawirus-w-polsce-jak-covid-19-uderza-w-firmy-badanie/k49g81q

Frishkoff, P.A. (1995). Understanding family business: What is a family business. Oregon State University, Austin Family Business Program, 15, 19.

Habbershon, T.G., \& Williams, M.L. (1999). A resource-based framework for assessing the strategic advantages of family firms. Family Business Review, 12(1), 1-25. doi:10.1111/j.1741-6248.1999.00001.x

Kraus, S., Clauss, T., Breier, M., Gast, J., Zardini, A., \& Tiberius, V. (2020). The economics of COVID-19: initial empirical evidence on how family firms in five European countries cope with the corona crisis. International Journal of Entrepreneurial Behaviour and Research, 26(5).

doi:10.1108/IJEBR-04-2020-0214

Kukuła, K. (1999). Metoda unitaryzacji zerowanej na tle wybranych metod normowania cech diagnostycznych. Acta Scientifica Academiae Ostroviensis, 4, 5-31.

Lee, J. (2006). Family firm performance: Further evidence. Family Business Review, 19(2), 103-114.

Lins, K.V, Volpin, P., \& Wagner, H.F. (2013). Does family control matter? International evidence from the 2008-2009 financial crisis. Review of Financial Studies, 26(10), 2583-2619.

doi: $10.1093 /$ rfs/hht044

Miller, D., \& Le Breton-Miller, I. (2006). Family governance and firm performance: Agency, stewardship, and capabilities. Family Business Review, 19(1), 73-87. doi:10.1111/j.1741-6248.2006.00063.x

Minichilli, A., Brogi, M., \& Calabrò, A. (2015). Weathering the storm: Family ownership, governance, and performance through the financial and economic crisis. Corporate Governance: An International Review, 24(6). doi:10.1111/corg.12125

Neckebrouck, J., Schulze, W., \& Zellweger, T. (2018). Are family firms good employers? Academy of Management Journal, 61(2), 553-585.

PWC. (2020). Polski mikro, maty i średni biznes w obliczu pandemii COVID 19. Przychody, plynność i reakcja na wstrzas. Retrieved from https://www.pwc.pl/pl/pdf/polski-mikro-maly-sredni-biznes-wobliczu-pandemii.pdf

Siakas, K., Naaranoja, M., Vlachakis, S., \& Siakas, E. (2014). Family businesses in the new economy: How to survive and develop in times of financial crisis. Procedia Economics and Finance, 9(14), 331-341. doi:10.1016/s2212-5671(14)00034-3

Sirmon, D.G., \& Hitt, M.A. (2003). Managing resources: Linking unique resources, management, and wealth creation in family firms. Entrepreneurship: Theory and Practice, 27(4), 339-359. 
Songini, L. (2006). The professionalization of family firms: Theory and practice. In P. Poutziouris, K. Smyrnios, S. Klein (eds.), Handbook of Research on Family Business (pp. 269-297). Northampton: Edward Elgar Publishing.

Ustawa o zmianie ustawy o szczególnych rozwiązaniach związanych z zapobieganiem, przeciwdziałaniem i zwalczaniem COVID-19, innych chorób zakaźnych oraz wywołanych nimi sytuacji kryzysowych oraz niektórych innych ustaw (Dz.U. 2020 poz. 568).

Ustawa o szczególnych instrumentach wsparcia w związku z rozprzestrzenianiem się wirusa SARS-CoV-2 (Dz.U. 2020, poz. 695).

Ustawa o zmianie niektórych ustaw w zakresie działań osłonowych w związku z rozprzestrzenianiem się wirusa SARS-CoV-2 (Dz.U. 2020 poz. 875).

Ustawa o dopłatach do oprocentowania kredytów bankowych udzielanych przedsiębiorcom dotkniętym skutkami COVID-19 oraz o uproszczonym postępowaniu o zatwierdzenie układu w związku z wystąpieniem COVID-19 (Dz.U. 2020 poz. 1086).

Wenzel, M., Stanske, S., \& Lieberman, M.B. (2020, April). Strategic responses to crisis. Strategic Management Journal, 7-18. doi:10.1002/smj.3161

Węcławski, J., \& Żukowska, B. (2019). Refreshing typologies based on family firms' goals: The perspective of "first-generation enterprises." Central European Management Journal, 27(3), 128-146. doi:10.7206/cemj.2658-0845.6

Zajkowski, R., \& Życzyński, N. (2014). Percepcja a rzeczywiste wyróżniki przedsiębiorstw rodzinnych. Economics and Management, 6(3), 236-247. doi:10.12846/j.em.2014.03.16

\section{Websites}

www.300gospodarka.pl/live/koronawirus-nowe-ograniczenia-w-polsce www.dziennikustaw.gov.pl/

www.gov.pl

www.pfr.pl/tarcza.html

www.pracodawcyrp.pl/tarcza-antykryzysowa 